\title{
Growth and Yielding Potential of Hot Pepper Varieties under Rain-Fed Production at Woreta, Northwestern Ethiopia
}

\author{
Dessie Getahun, Birhanu Habtie \\ Ethiopian Institute of Agricultural Research (EIAR), Fogera Research Center \\ desdesgetahun@gmail.com
}

\begin{abstract}
Hot pepper is a widely grown vegetable, spice and condiment crop in Ethiopia, whose fruits are consumed as fresh, dried or processed products. It is also a major cash crop with high domestic-and export value. The use of unimproved local varieties of low quality and productivity, and soil borne and foliar diseases caused by fungi, bacteria and viruses are among several constraints the production system for green and dry pod confronted with. Field experiments were carried out to evaluate dynamics of growth, resistance /tolerance to disease and yielding potential of hot pepper varieties at Fogera Agricultural Research Center during the rainy seasons of 2014 and 2015. Five varieties namely, Markofana, Melkazala, Melkaawaze, Melkashote and a local check were laid in a randomized complete block design with three replications. The interaction between year and variety was found insignificant, where as varieties performed significantly different ( $p<0.05)$ for most parameters considered in the study. The result revealed that varieties Melkazala and Melkaawaze were the most tolerant /resistant to disease attack with significantly $(p<0.05)$ high green pod yield of 13.00 and 14.53 ton per hectare, respectively. Besides promoting both Melkaawaze and Melkazala varieties for wide spread production in Fogera and other areas with similar agro-ecological conditions, the latter could also be used in breeding programs to transfer useful traits such as disease tolerance /resistance.
\end{abstract}

Keywords: Capsicum, disease, green pod, rain-fed, Woreta.

\section{INTRODUCTION}

Hot pepper (Capsicum species) belongs to the Solanaceae family and originated in the new world tropics and subtropics (Mexico, Central America and Andes of South America) over 2000 years ago (Walter, 1986 and Rodriguez et al., 2008). The genus Capsicum consists of approximately 22 wild species and five domesticated species, which include C. annum L., C. frutescens L., C. chinenses L., C. baccatum L., and C. pubescens L. (Bosland and Votava, 2000, Patricia et al., 2003 and Pickersgill, 1997). The $C$. апnиum complex, which includes three closely related species, C. annuиm, $C$. frutescens and $C$. chinenses are the most widely grown in the Americas and worldwide. C. annuиm has been domesticated in the highlands of Mexico, and includes most of the Mexican chilli peppers, most of the hot peppers in Africa and Asia and the various cultivars of sweet peppers grown in temperate countries. $C$. frutescens and $C$. chinenses are cultivated in Africa and Asia as spice crop, as intact fruits or for their oleoresin content. The other two species namely $C$. baccatum and $C$. pubescens are predominantly confined to Latin America (Pickersgill, 1997).

Peppers are grown extensively under various environmental and climatic conditions. It is an important cash crop for smallholder farmers in developing countries such as Ethiopia, Nigeria, Ghana, China, India, Pakistan, Bhutan, Indonesia, Cambodia, and Thailand (Lin et al., 2013). In many countries of the world, pepper is a cash crop with high domestic- and export value. According to Lin et al. (2013), uses of pepper are generally grouped into five broad market categories: (i) fresh market (green, red, multi-color whole fruits), (ii) fresh processing (sauce, paste, canning, pickling), (iii) dried spice (whole fruits and powder), (iv) industrial extracts (paprika/ oleoresin, capsaicinoids and carotenoids) and (v) ornamental (plants and /or fruits).

Peppers are widely grown in various parts of Ethiopia and the fruits are consumed as fresh, dried or processed products, as vegetables, as spices or condiments. Today, the crop has not only attained economical, but also traditional importance. It is one component of the daily diet of Ethiopian people. Peppers are important in the local dishes as 'karia' (green pod), 'berbere' (fine powder from the dry 
fruits of hot pepper), grinded mature green fruits blended with other spices and 'mitmita', the small very pungent fruits. The powder from dried ripe fruits of hot pepper is used as spice to flavor 'Wot', an Ethiopian stew in a daily traditional meal. Mature green pods ('karia') are eaten as salads.

Unless the sauce (stew) is 'alcha' (prepared without the use of hot pepper powder), 'berbere' is used daily in almost all Ethiopian house as a culinary spice in the preparation of stew (sauce) to yield the desired color, flavor and pungency. Fine pungent powder of hot pepper ('berbere') is an indispensable flavoring and coloring ingredient in the daily preparation of different types of Ethiopian sauces ('wot'), whereas the green pod is consumed as a vegetable with other food items (MARC, 2004). Green pods ('karia') are not eaten only fresh as vegetables, but also grinded and eaten with 'injera' (Ethiopian flat pancake prepared from grains of 'tef' (Tef eragrostis) or bread or with other food items and also used as ingredient of sauce. In all cases, powder of red pepper or grinded green pods is blended with other spices to add more color and flavor.

Pepper is a very important crop for spice extraction since it has a lot of Oleoresin for dying of food items and Ethiopia is among few developing countries that have been producing paprika and capsicum oleoresins for export market (MoARD, 2007). The crop is exported as dried ripe fruit or as oleoresin extracted from the fruits (Yosef and Yayehu, 1989). Today, small-scale farmers produce the largest proportion of hot pepper in the country. In many areas, pepper is grown predominantly as monocrop, and rotated with cereals or legumes, using the main rainy season. However, pockets of production in the dry season using irrigation can be found, particularly in the rift valley parts of Ethiopia.

Despite enormous uses of pepper as vegetable and spice, medicine, ornamental, and extensive pepper production practiced in Amhara region in particular and in Ethiopia in general, the production system for green and dry pod is confronted with several constraints. Absence of improved varieties and lack of pure seed supply are among major challenges of production. Zekarias (2012) reported that unimproved local varieties, namely marco (in Omo Nada) and kolesh (in Gojeb) are used in southwest Ethiopia, which attributed to low productivity and poor product quality. Farmers usually use local varieties of low quality seed with poor growth performance and low productivity. Susceptibility of local varieties to diseases is also among the major challenges of the production practice. Various diseases caused by viruses, bacteria and fungi and insect pests have emerged as serious threat of this crop in the major producing areas. Furthermore, the use of unimproved traditional horticultural husbandry such as fertilization are partly attributable to low productivity and quality. Shiferaw and Alemayehu (2014) indicated that a complex of diseases exist at each growth stage of hot pepper and the occurrence across districts was highly variable despite introduction and promotion of different management practices in southern Ethiopia. Pepper in Ethiopia can be produced both under rainfed and using irrigation. Valipour (2013) showed that $46 \%$ of the world is not suitable for rainfed agriculture and $80 \%$ of agricultural production is from rainfed areas, and further recommended agricultural integration is an affordable approach. According to Valipour (2012) determining critical periods and areas of water requirement is essential to increase productivity and water use efficiency.

Farmers use to grow mostly local selections, because there are shortages of improved varieties. Seeds are either from former harvests or bought from local markets. Such seed lots are often mixtures of different varieties with impurities harboring pathogens. Availability of varieties with high productivity and quality for 'bereber' (powder form) and green pepper that are widely adaptable and resistant/tolerant to major diseases and insect pests are lacking. Introduction and selection for best adaptable varieties with high yield and quality as well as resistant to biotic and abiotic environmental stresses is therefore a priority and quick approach to contribute towards alleviating major bottlenecks of the existing production system. According to Mskuwa et al., (2016), introduction, domestication and commercialization of plants play a major role in improving rural livelihoods through nutritional status, household income, entrepreneurial opportunities and economic empowerment.

The use of unimproved local varieties of low quality and productivity, and soil borne and foliar diseases caused by fungi, bacteria and viruses are among several constraints the production system for green and dry pod confronted with. Varieties with high productivity and quality for dry pod (powder form) and green pepper that are widely adaptable and resistant/tolerant to major diseases and insect pests are lacking, As a result, production and productivity of pepper is declining and farmers are abandoning pepper production in many places around the study area. This growth performance and yielding potential evaluation of varieties was therefore undertaken to indentify best varieties for 
disease resistance /tolerance, high green pod yield and quality around Fogera district in Northwestern Ethiopia.

\section{Materials AND MethodS}

\subsection{Description of the Study Area}

The experiment was conducted at Fogera Agricultural Research Center during the rainy season of 2014 and 2015. The Center is found in Woreta town of Fogera district of South Gondar Administrative zone in Amhara Region, Ethiopia. Woreta lies at $11^{\circ} 58^{\prime} \mathrm{N}$ latitude and $37^{\circ} 41^{\prime} \mathrm{E}$ longitude. It has an altitude of $1819 \mathrm{~m}$ above sea level and receives average annual rainfall of 1230 $\mathrm{mm}$. Mean minimum and maximum temperature of the area is 12 and $28^{\circ} \mathrm{C}$, respectively. Soil of the site is red clay (vertisol) with a $\mathrm{pH}$ of 5.48 .

\subsection{Plant Material and Seedling Raising}

Seeds of four improved hot pepper varieties, namely, Markofana, Melkazala, Melkaawaze and Melkashote were obtained from Melkassa agricultural research center of the Ethiopian Institute of Agricultural Research, and seeds of a local hot pepper were purchased from Woreta market. Seedlings of five varieties (four improved and one local) were raised in a nursery. Seedlings of each variety were raised on $2 \mathrm{~m} \times 1 \mathrm{~m}$ (adjacent plots) thoroughly prepared beds, $5 \mathrm{~cm}$ raised from the surface (Figure 1). Seeds were drilled on rows with ten $\mathrm{cm}$ inter-row spacing and it was covered lightly with fine soil and mulched with dried grass until emergence. Weeding was accomplished as deemed necessary. Seedlings were thinned at first true leaf stage to allow sufficient distance within seedlings. Seeds for the first experiment were sown in a nursery on $21^{\text {st }}$ May 2014 and transplanting in the field was made on $22^{\text {nd }}$ July 2014 where as in the second year seeds were sown in a nursery on $21^{\text {st }}$ May 2015 and transplanting in the field was made on $14^{\text {th }}$ July 2015.

\subsection{Experimental Design and Pre-Harvest Field Management}

Experimental field was thoroughly plowed and leveled, and ridges were then prepared on sides of which transplanting was done (Figure 1). Experimental design employed to evaluate the performance of five varieties was randomized complete block with three replications. An effective plot size of 4.0 $\mathrm{m}$ by $3.6 \mathrm{~m}$ with $40 \mathrm{~cm}$ and $60 \mathrm{~cm}$ intra- and inter-row, respectively, spacing was used, accommodating 60 plants in six rows for each treatment. Gangways in between replications and plots were, in that order, $1.5 \mathrm{~m}$ and $1 \mathrm{~m}$ wide. Both trials in 2014 and 2015 were carried out during the rainy period without supplementary irrigation.

Inorganic fertilizers in the form of Urea (46:0:0) and Diamonium phosphate (DAP) (18:46:0) both at the rate of $100 \mathrm{~kg} / \mathrm{ha}$ (kilogram per hectare) were applied. DAP was applied at transplanting while urea is applied in two splits, the first at transplanting and the second one and half months from transplanting. Standard field management practices such as weeding and cultivation were performed uniformly during the growing seasons.

\subsection{Data Collection}

Disease incidence was regularly observed and recorded using one to five score where five refers to $100 \%$ attack, all leaves and plants developing severe symptoms. Seedling emergence, vigor and field establishment after transplanting were also observed. Data was collected on plant height at first harvest. It is measured from the soil surface up to the tip of main branch. A total of six consecutive harvests, at a week interval, were made from a plot. Fruit yield (green pod) was harvested at appropriate maturity time and weight was taken for each treatment. Harvested pods were categorized into marketable and non marketable fruits. Mature green pods with visible damages, cracks, blemishes and discoloration due to biotic and abiotic stresses were considered non marketable. Hundred pod weight was also recorded by randomly taking pods from marketable fruits. Data was subjected to analysis of variance using SAS software version 9.2 and least significance difference (LSD) was used to compare treatment means when there was statistically significant difference $(\mathrm{P}<0.05)$.

\section{RESUlT}

Six consecutive harvests, at a week interval, were made from every plot of experiments executed in 2014 and 2015 growing seasons. The first harvest was made in the third week of October while the 
last was made in the first week of December. Performance of varieties was significantly different $(\mathrm{P}<0.05)$ for most parameters considered (disease, plant height, fresh fruit yield, 100 pod weight) in the study, while the interaction between year and varieties was found insignificant.

The highest total mean green pod yield in 2014 and in 2015 was obtained from variety Melkaawaze (13.734 and 15.323, respectively) while the lowest was from variety Markofana (Table 1).

Table 1. Mean green pod yield of hot pepper varieties in ton per hectare.

\begin{tabular}{|l|l|l|l|l|l|l|}
\hline & \multicolumn{2}{|l|}{2014 growing season } & \multicolumn{2}{l|}{ 2015 growing season } & \multicolumn{2}{l|}{ Combined } \\
\hline Variety & $\begin{array}{l}\text { First three } \\
\text { harvest }\end{array}$ & $\begin{array}{l}\text { Total (six) } \\
\text { harvest }\end{array}$ & $\begin{array}{l}\text { First three } \\
\text { harvest }\end{array}$ & $\begin{array}{l}\text { Total (six) } \\
\text { harvest }\end{array}$ & $\begin{array}{l}\text { First three } \\
\text { harvest }\end{array}$ & $\begin{array}{l}\text { Total } \\
\text { harvest }\end{array}$ \\
\hline Markofana & $1.385^{\mathrm{b}}$ & $3.823^{\mathrm{b}}$ & $1.68^{\mathrm{b}}$ & $5.060^{\mathrm{b}}$ & $1.532^{\mathrm{c}}$ & $4.441^{\mathrm{c}}$ \\
Melkazala & $6.430^{\mathrm{a}}$ & $11.913^{\mathrm{a}}$ & $7.492^{\mathrm{a}}$ & $12.485^{\mathrm{a}}$ & $6.961^{\mathrm{a}}$ & $13.000^{\mathrm{a}}$ \\
Melkaawaze & $7.792^{\mathrm{a}}$ & $13.734^{\mathrm{a}}$ & $9.840^{\mathrm{a}}$ & $15.323^{\mathrm{a}}$ & $8.838^{\mathrm{a}}$ & $14.529^{\mathrm{a}}$ \\
Melkashote & $2.980^{\mathrm{b}}$ & $6.629^{\mathrm{b}}$ & $4.507^{\mathrm{b}}$ & $11.057^{\mathrm{a}}$ & $3.743^{\mathrm{b}}$ & $8.843^{\mathrm{b}}$ \\
Local & $2.263^{\mathrm{b}}$ & $5.317^{\mathrm{b}}$ & $2.731^{\mathrm{b}}$ & $5.416^{\mathrm{b}}$ & $2.497^{\mathrm{bc}}$ & $5.366^{\mathrm{c}}$ \\
\hline CV\% & & 28.47 & 29.54 & 29.43 & 32.89 & 28.32 \\
LSD(5\%) & 3.053 & 4.440 & 2.95 & 5.468 & 1.879 & 3.118 \\
\hline Interaction & $\mathrm{NS}$ & $\mathrm{NS}$ & $\mathrm{NS}$ & $\mathrm{NS}$ & NS & NS \\
Variety*year & & & & & & \\
\hline
\end{tabular}

Means followed with the same letter within a column are not significantly different at $\mathrm{P}<0.05$.

Variety Melkazala had better tolerance /resistance to disease attack than variety Melkaawaze and significantly better than the other three varieties (Table 2). The major disease observed in 2014 and 2015 was bacterial leaf spot. Shiferaw and Alemayehu (2014) also showed that fungal (Fusarium wilt and powdery mildew) and bacterial (wilt, leaf spot and soft spot) and virus diseases are the most frequently encountered diseases in hot pepper producing areas of southern Ethiopia. Combined mean result showed that Melkaawaze was the tallest variety $(70.15 \mathrm{~cm})$ while local variety had he shortest height $(47.95 \mathrm{~cm})($ Table 2$)$.

Table 2. Mean disease score and plant height of hot pepper varieties.

\begin{tabular}{|c|c|c|c|c|c|c|}
\hline & \multicolumn{3}{|c|}{ Disease score (1-5 scale) } & \multicolumn{3}{c|}{ Plant height in cm } \\
\hline Variety & 2014 & 2015 & Combined & 2014 & 2015 & Combined \\
\hline Markofana & $1.50^{\mathrm{b}}$ & $1.50^{\mathrm{c}}$ & $1.50^{\mathrm{c}}$ & $55.47^{\mathrm{b}}$ & $52.97^{\mathrm{ab}}$ & $54.22^{\mathrm{bc}}$ \\
Melkazala & $0.37^{\mathrm{a}}$ & $0.50^{\mathrm{a}}$ & $0.43^{\mathrm{a}}$ & $70.20^{\mathrm{a}}$ & $56.00^{\mathrm{ab}}$ & $63.10^{\mathrm{ab}}$ \\
Melkaawaze & $0.83^{\mathrm{a}}$ & $1.00^{\mathrm{b}}$ & $0.92^{\mathrm{a}}$ & $71.47^{\mathrm{a}}$ & $68.83^{\mathrm{a}}$ & $70.15^{\mathrm{a}}$ \\
Melkashote & $1.50^{\mathrm{b}}$ & $1.50^{\mathrm{c}}$ & $1.50^{\mathrm{c}}$ & $48.30^{\mathrm{b}}$ & $56.93^{\mathrm{ab}}$ & $52.62^{\mathrm{bc}}$ \\
Local & $2.33^{\mathrm{c}}$ & $2.00^{\mathrm{d}}$ & $2.17^{\mathrm{d}}$ & $49.13^{\mathrm{b}}$ & $46.77^{\mathrm{b}}$ & $47.95^{\mathrm{c}}$ \\
\hline CV\% & 20.58 & 17.20 & 18.26 & 9.23 & 20.02 & 16.65 \\
LSD(5\%) & 0.51 & 0.42 & 0.29 & 10.24 & 21.23 & 11.64 \\
\hline Interaction & $\mathrm{NS}$ & $\mathrm{NS}$ & $\mathrm{NS}$ & $\mathrm{NS}$ & $\mathrm{NS}$ & NS \\
Variety*year & & & & & & \\
\hline
\end{tabular}

Means followed with different letters within a column are significantly different at $\mathrm{P}<0.05$.

Mean 100 green pod weight of variety Markofana and Melkazala was superior than the other three cultivars (Table 3). Mean pod weight in 2014 varied from 5.42 to $9.04 \mathrm{~g}$ where as in 2015 it ranged from 6.41 to $8.07 \mathrm{~g}$. Overall mean pod weight depicted that the lowest pod weight was for variety Melkashote while the highest was for variety Melkazala. In agreement to the present finding, Awole et al. (2011) reported that mean pod weight of five pepper varieties to be in the range of 6.6 and $17 \mathrm{~g}$. Nsabiyera et al. (2012) also indicated that pepper genotypes varied from $1.1-16.2 \mathrm{~g}$ in their mean fruit weight.

Table 3. Mean 100 green pod weight of hot pepper varieties.

\begin{tabular}{|c|c|c|c|}
\hline & \multicolumn{3}{|c|}{ 100 green pod weight in gram } \\
\hline Variety & 2014 & 2015 & Combined \\
\hline Markofana & $842^{\mathrm{ab}}$ & 807 & $824^{\mathrm{ab}}$ \\
Melkazala & $904^{\mathrm{a}}$ & 788 & $846^{\mathrm{a}}$ \\
Melkaawaze & $661^{\mathrm{abc}}$ & 641 & $651^{\mathrm{bc}}$ \\
Melkashote & $542^{\mathrm{c}}$ & 659 & $601^{\mathrm{c}}$ \\
Local & $601^{\mathrm{bc}}$ & 656 & $628^{\mathrm{c}}$ \\
\hline
\end{tabular}


Growth and Yielding Potential of Hot Pepper Varieties Under Rain-Fed Production at Woreta, Northwestern Ethiopia

\begin{tabular}{|c|c|c|c|}
\hline CV\% & 21.8 & 15.85 & 21.45 \\
LSD(5\%) & 292 & 212 & 185 \\
\hline Interaction & NS & NS & NS \\
Variety*year & NS & \\
\hline
\end{tabular}

Means followed with different letters within a column are significantly different at $\mathrm{P}<0.05$.

The highest percentage non marketable fruit was recorded from local variety $(4.26 \%)$ in 2014 , where as the lowest is from variety Markofana $(0.33 \%)$. Similarly, local variety $(4.5 \%)$ and Melkaawaze (4.4\%) had the highest percentage non marketable fruit in 2015. Except for variety Melkashote, per cent non marketable pepper is higher in 2015 than in 2014 (Figure 2).

\section{DISCUSSION}

Combined mean green pod yield revealed that Variety Melkaawaze (14.529 ton) followed by Melkazala (13.0) produced significantly high pod yield than the other cultivars. In 2014 and 2015 growing seasons, the highest total green pod yield was obtained from variety Melkaawaze followed by Melkazala while the lowest yield was from variety Markofana (Table 1; Figure 3). This is associated with superior vegetative growth including height, and tolerance to disease attack. Although the highest green pod yield was obtained from variety Melkaawaze, it was not significantly different from the yield obtained from variety Melkazala (Table 1). Gebremeskel et al. (2015) also found that variety Melkaawaze was the highest yielding under irrigation at Raya valley, Tigray Ethiopia. It is therefore demonstrated that performance of Varieties Melkaawaze and Melkazala were superior in various locations with similar agro-climatic conditions. Moreover, these two varieties performed best both in the main season under rain fed production and in the dry season using irrigated production. It can therefore be inferred that these varieties are adaptable to wider locations including suitability to different production systems in the rainy season and during the dry period using irrigation.

In addition to varieties with specific adaptation for specific location, varieties with wide adaptation are crucial to Ethiopian situation with varied agro-ecological conditions. In many areas of the world including Ethiopia, water resources are limited and irrigation is not economical (Valipour, 2013). It is therefore indisputable to develop or identify varieties with high productivity and good quality under rain fed production.

Despite its good fruit quality for 'berbere' and 'karia', poor vegetative growth during the rainy season was observed from variety Markofana . Performance of variety Markofana was poor during the rainy season, reviving to flourish with good vegetative growth later in the end of the rainy season when other varieties started turning into good reproductive stage. Further vegetative growth of Markofana was however limited and dried prematurely due to absence of irrigation water supply during the dry season. This presumably reflected that this variety could be suitable to dry season production using irrigation.

Local variety was the most susceptible to disease attack and even symptom development started at seedling stage in the nursery. This is presumably attributable to the use of impure seeds harboring inoculums of pathogens. According to Shiferaw and Alemayehu (2014), out of 90 seed beds assessed in south Ethiopia, 55\% of seed beds were infected by seedling diseases.

Slow growth at seedling stage from variety Melkazala was compensated with noticeably quick vegetative growth after field establishment and during the reproductive phase. Moreover, variety Melkazala had dark green foliage color and was the most tolerant variety to disease attack. Though insignificant when compared with variety Markofana, Melkazala had also the highest overalls mean pod weight.

Tolerance / resistance to disease attack of these two varieties (Melkazala and Melkaawaze) accompanied with their best vegetative growth including height were attributable to their best performance in yield. In addition to direct promotion for widespread production of varieties Melkaawaze and Melkazala, the latter variety could preferably be used in breeding program to transfer disease tolerance /resistance traits. Since Melkazala had very slow seedling growth and generally slow vegetative growth at early stage, complementing parents for breeding could be those with fast growth habit at an early stage and /or good pod quality. 


\section{Conculusion}

The use of disease infected seeds and seedlings and inoculums from the soil are causing complete failure of pepper plants at vegetative stage. Many farmers in Amhara region are therefore abandoning pepper production due largely to diseases caused by fungi and bacteria. It is a priority task to identify parental lines for launching breeding programs targeted to develop varieties with high yield, superior quality and resistance / tolerance to biotic and abiotic stresses. Furthermore, availing healthy seeds with high productivity and product quality is crucial. Varieties Melkazala and Melkaawaze had the best growth performance and were found the most tolerant to disease attack ultimately producing significantly high total green pod yield. These varieties could therefore be promoted for wide spread production by multiplying healthy and pure seeds.

Since Ethiopia has a diversified agro-ecology varying in climatic and edaphic conditions from location to location, research supported recommendations of varieties of wide and specific adaptation are essential. Variety Melkazala could be used in breeding program to transfer disease resistance /tolerant traits. Since Variety Melkazala is slow in growth characteristics at seedling stage, complementing parents could be those with fast growth habit at an early stage and /or good pod quality. Further development of varieties through breeding and promotion of improved varieties with high productivity and product quality, and resistance /tolerance to biotic and abiotic stresses are therefore indispensable.
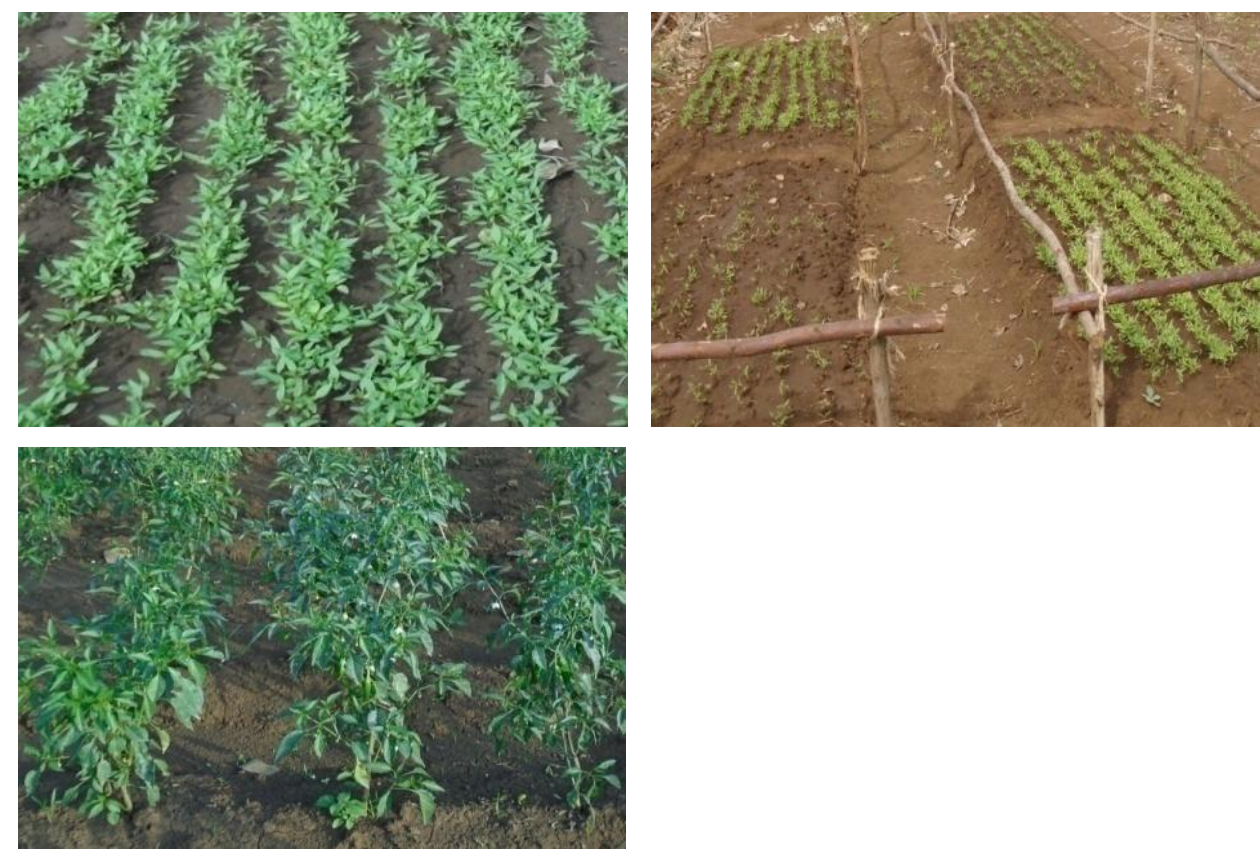

Figure 1. Seedling raising and transplanted pepper on sides of ridges.

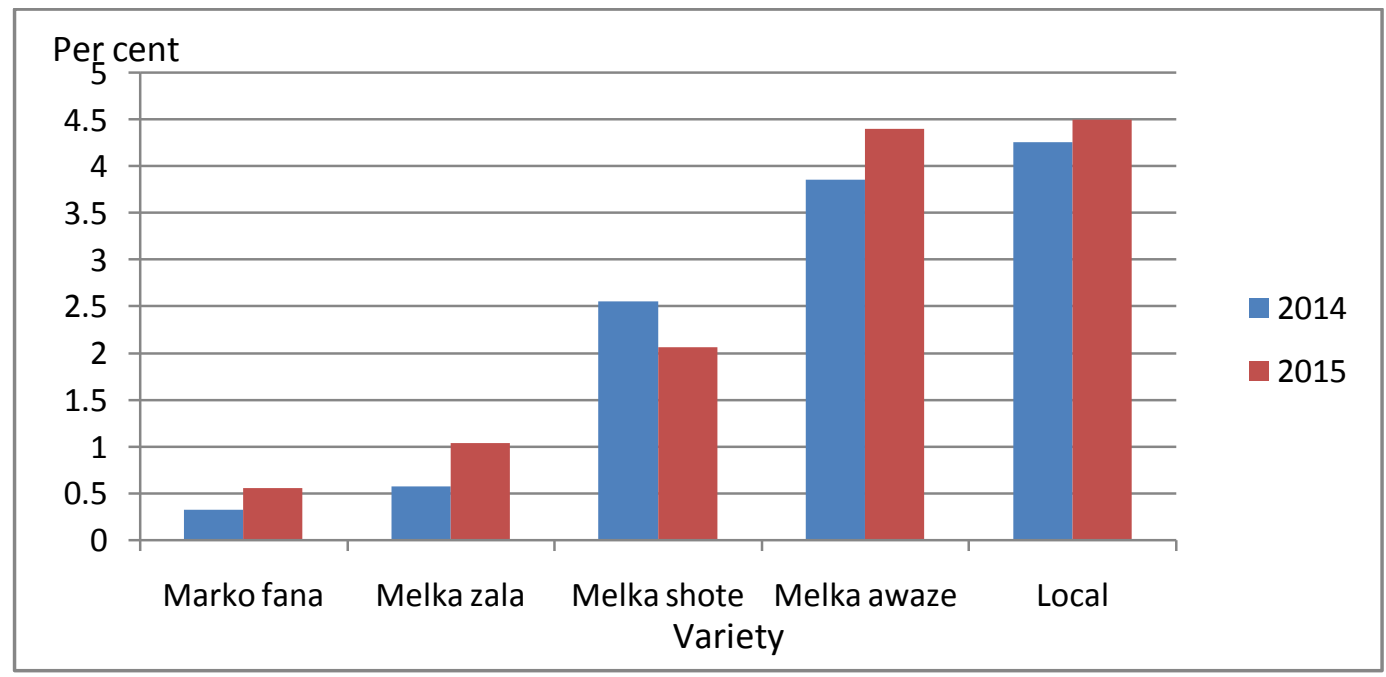

Figure 2. Mean percentage non marketable green pods. 


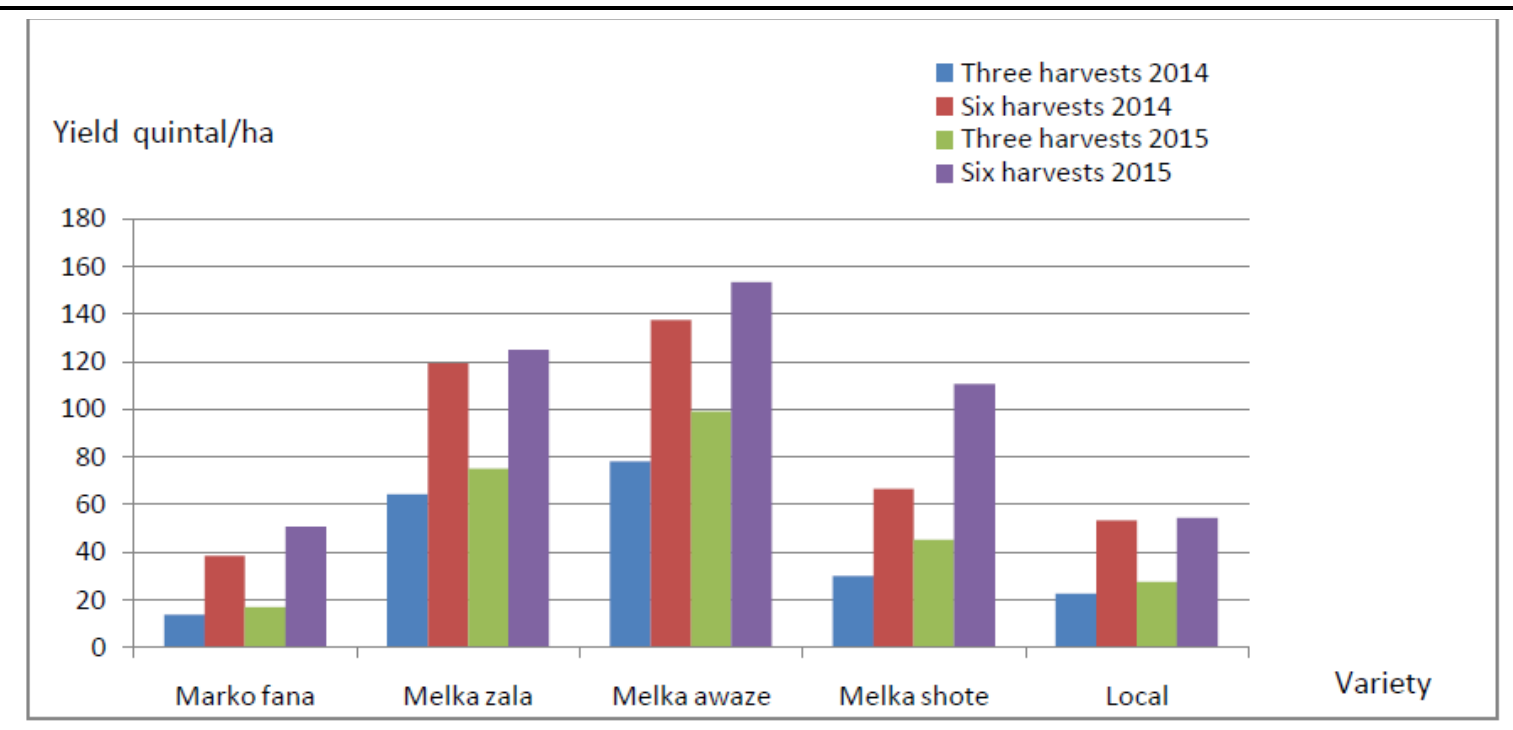

Figure 3. Mean total green pod yield in quintal per hectare.

\section{ACKNOWLEDGEMENT}

Authors are grateful to Mr. Dejene Bikis for his assistance during data collection in 2015. Vegetable research team of Melkassa Agricultural Research Center of the Ethiopian Institute of Agricultural Research is also acknowledged for the support of providing us with seeds of improved pepper varieties.

\section{REFERENCES}

[1] Awole S, Woldetsadik K, Workneh TS (2011). Yield and storability of green fruits from hot pepper cultivars (Capsicum spp.). African Journal of Biotechnology, 10(56):12662-12670

[2] Bosland PW, Votava EJ (2000). Peppers: Vegetable and Spice Capsicums. Crop Production Science in Horticulture, CABI Publishers.Pp.304

[3] Gebremeskel H, Abebe H, Wakuma BW, Jelato K (2015). Performance evaluation of hot pepper (Capsicum annum L.) varieties for productivity under irrigation at Raya Valley, Northern, Ethiopia. Basic Research Journal of Agricultural Science and Review, 4(7): 211-216

[4] Lin S WL, Chou Yu, Ching S H, Andreas W, Ebert S K, Ravza M, Albert R, Abdou T, Victor A and Paul A G ( 2013). Pepper (Capsicum spp.) Germplasm Dissemination by AVRDC - The World Vegetable Center: an Overview and Introspection. CHRONICA HORTICULTURAE, 53 (3)

[5] MARC (Melkasa Agricultural Research Center) (2004). Progress Report, Addis Ababa, Ethiopia

[6] MoARD (2007). Crop Variety Register, Crop Development Department: Issue No. 10, June 2007. Ministry of Agriculture and Rural Development, Addis Abeba, Ethiopia

[7] Msukwa V, Munthali CRY, Missanjo E, Chilima CZ, Simon A, Mng'omba SA, Sagona W, Mkwezalamba I (2016). Growth Performance and Fruit Production of Sclerocarya birrea (A. Rich.) Hochst. Provenances in Malawi. International Journal of Scientific Research in Agricultural Sciences, 3(2), pp. 042-049

[8] Nsabiyera V, Ochwo-ssemakula M, Sseruwagi PP (2012). Field performance and quality traits of hot pepper genotypes in Uganda. African crop science journal, 20 (1): 123 - 139

[9] Patricia T, Rodriguez F, Martinez E, Duque MC, Tohme J (2003). Molecular characterization by AFLPs of Capsicum germplasm from the Amazon department in Colombia, characterization by AFLPs of Capsicum. Genetic resources and crop evolution, 50: 639-647

[10] Pickersgill B (1997). Genetic resources and breeding of Capsicum spp. Euphytica , 96:129-133

[11] Rodríguez Y, Depestre T, Gómez O (2008). Efficiency of selection in pepper lines (Capsicum annиum) from four subpopulations in characters of productive interest. Ciencia e Investigación Agraria, 35(1):29-40

[12] Shiferaw M, Alemayehu C (2014). Assessment of Hot Pepper (Capsicum species) Diseases in Southern Ethiopia. International Journal of Science and Research, (IJSR).3(3) 
[13] Valipour M (2012). Hydro-Module Determination For Vanaei Village In Eslam Abad Gharb, Iran. ARPN Journal of Agricultural and Biological Science. 7: 968-976

[14] Valipour M (2013). Necessity of Irrigated and Rainfed Agriculture in the World. Irrigat Drainage Sys Eng S9:e001. doi:10.4172/2168-9768.S9-e001

[15] Walter H (1986). Green leaf. In: Breeding Vegetable Crops. Westport, Connecticut: AVI Publishing, Co.

[16] Yosef H, Yayehu Z (1989). Hot pepper and tomato production in Ethiopia. In: Green, SK, Giggs, TD, Mclean, BT (eds.). Tomato and pepper production in the Tropics, Pp 442-451

[17] Zekarias S (2012). Hot pepper production and marketing in southwest Ethiopia. An alternative enterprise for small scale farmers, Trends in agricultural economics, 5: 83-95. 